\title{
The Landscape of Sound in the
}

\section{Nineteenth and Twentieth}

\section{Centuries}

\author{
LUDOVIC TOURN È S
}

Alain Corbin, Les cloches de la terre. Paysage sonore et culture sensible dans les campagnes au XIXe siècle (Paris: Flammarion, I994), 359 pp., €8.69 (pb), ISBN 20808 I 4532.

Glenn Watkins, Proof through the Night. Music and the Great War (Berkeley, Los Angeles and London: University of California Press, 2003), 598 pp., \$49.95 (hb), ISBN 052023 I 589.

Jeffrey Jackson, Making Jazz French. Music and Modern Life in Interwar Paris (Durham, NC, and London: Duke University Press, 2003), 266 pp., \$2 I.95 (pb), ISBN 082233 I 373.

Bernard Gendron, Between Montmartre and the Mudd Club. Popular Music and the Avant-Garde

(Chicago and London: University of Chicago Press, 2003), 388 pp., \$55.00 (hb), ISBN $022628735 \mathrm{I}$.

David Looseley, Popular Music in Contemporary France (Oxford and New York: Berg, 2003), 254 pp.,

$\$ 25.00(\mathrm{pb})$, ISBN I 8597363 I9.

Though undoubtedly thriving, the history of music is still a somewhat peripheral area of research which many historians dismiss as secondary. For many years publication in the subject remained the domain of two kinds of researchers, either musicologists 'insiders' au fait with the technical vocabulary - or sociologists and practitioners of 'cultural studies' - 'outsiders' chiefly interested in the reception of musical phenomena and their role in the constitution of individual and collective identities. This division has become very blurred over the last few years, which have seen the emergence of a number of works with an interdisciplinary approach. But for most historians the history of music remains a largely unfamiliar theme which they struggle to include in any global social or cultural analysis. This struggle is apparent at two levels: first, the difficulty of developing guidelines to the historicity of musical events and, second, the difficulty of escaping the chronology of classical music, which is predicated on a succession of styles and composers. Based on these two points, this article will attempt to develop, through a transverse reading of certain recent works, some working hypotheses centring on the notion of a 'landscape of sound' or paysage sonore, as proposed some ten years ago by Alain Corbin, a notion which, it seems to me, may make a valuable contribution to rejuvenating the history of music. 


\section{Changes in auditory sensibilities in the nineteenth century}

Alain Corbin's book is first and foremost an original contribution to the history of rural culture in nineteenth-century France, but it may also be useful to the historian of music either in its approach or in its proposed chronology. Focusing on the notion of a 'landscape of sound', Corbin starts from the assumption that eighteenth-century France was a 'society of silence', meaning one in which sound - or noise - was discontinuous, instead of continuous as in our own contemporary society, with its traffic, trains and aeroplanes, not to mention the omnipresent music (or muzak) which dogs us in both private and public places. Under the ancien régime, every commune had its church, whose bells made a 'web of sound' (p. 20) covering the entire area and doing much to shape the auditory world of its inhabitants. The sound of bells was, indeed, omnipresent in peasants' lives: not only did it have a religious connotation (it called them to mass), it also alerted them to important life events births, marriages and deaths - warned them of danger (fires) and punctuated their day by regular ringing. In other words, it had a fundamental symbolic role in the shaping of the village's collective identity. Corbin suggests that people in ancien régime society heard things differently from us, finding in the sound of church bells 'a system of affects now lost for ever' (p. I3). This loss took place in the nineteenth century, in three stages. First, in the decade from I789 to I799 the revolutionaries attempted to secularise rural space and time by force. They set out to 'deny communities' right to noise and dispute the need to sacralise space and time, and hence to modify the contours of cultural perception' (p. I7). They started by prohibiting bell-ringing for religious reasons, and then proceeded to carry off the bells themselves. This brutal policy did not fundamentally change the landscape of sound, however, because as soon as the Revolution was over the villages regained their bells - a token, if only a short-term one, of the failure of the revolutionaries' plans for cultural change. There was then a more 'decisive' change in the I860s (p. 97). Although there were no political upheavals during this period, the technical modernisation of France, the economic take-off and the rationalisation of time were all major factors in the 'abrupt changes to the culture of perception' (p. I3) made manifest as church bells lost their importance in local life. Finally, Corbin sees the I880s and the establishment of the Republic as the time when the landscape of sound became definitively secular. The republicans strove to assert their 'symbolic grip' (p. I83) on space at the expense of the Church - and succeeded where the revolutionaries of a century earlier had failed. This was for two main reasons: first, their method was much less violent than that in I789; second, the changes of the I860s had greatly weakened the bond between local people and their bells.

Apart from this chronological perspective Corbin also discusses, unfortunately without sufficient detail, an important phenomenon which he calls 'quantitative time' (p. I I I). Because it was measured arithmetically, this quantitative time brought about a gradual dissociation between the biological rhythm of peasants and the rhythm of the seasons which had previously regulated country life - not only work in the fields but also, more generally, every aspect of community and private life. From the i 860 s 
onwards the importance of bells as markers of time and sensibility steadily decreased, partly because they no longer measured time with sufficient precision, that is, they could not adapt to this new rationalisation of sensibility. It seems that this change was not due solely to the availability of new artefacts: as Corbin observes, the increasing demand for clocks from the I850s onwards was preceded (and doubtless facilitated) by 'a new demand for accuracy, a sharpened sense of urgency, an inarticulate demand for quantitative time' (p. I8I) in rural communities. No doubt this demand also existed, and was stronger, in towns, which were probably the primary sites for the development of the new landscape of sound.

It is worth asking whether this temporal rationalisation affected the world of music. It is striking that the new entertainment venues which arose in the I860s (the café-concert followed by the music hall) specified the timings for musical items. ${ }^{1}$ Equally striking, from the I 88 os onwards the development of the phonograph radically changed the way in which music was produced, disseminated and heard. This was surely one of the most important events in modern musical history. The phonograph is first and foremost a tool for rationalising and calibrating sound in both time and space, in that it limits listening time to a few minutes (this remained the case until the invention of the long-playing record in the I94OS). Thus the appearance of the phonograph at the end of the nineteenth century required the invention of a new way of listening to music: through a medium instead of directly, in private rather than in a concert hall. The time limit imposed by the apparatus brought the hearer very close to the work - the briefer the hearing, the closer the contact. In other words, the emergence of the 'fan' seems to have been closely dependent on the invention of recording.

Corbin's work easily convinces the reader that between the end of the eighteenth century and the end of the nineteenth a major change took place in the way in which people listened to sounds - in this case, the sound of bells. Did the same change take place in the world of music? Here the book seems to open some promising vistas on a domain still relatively unexplored by historians or musicologists. Corbin invites us to exchange the restrictive and reified framework of 'history of music' for a much richer one, the 'history of sounds' - anything from everyday noises to the highest forms of musical art - the framework that structures the auditory culture of a society. This provides an approach to questions which musical historians have barely touched on, even where reception is concerned: how does the hearer perceive the sound? What emotions does he associate with it? How is a 'culture of sound' created? How and why does a society assimilate new musical forms? What changes can be perceived to the frontiers between noise, sound and music? Can the story be divided into distinct chronological periods? Such questions may lead us towards an analysis of the history of hearing which is still in its infancy. ${ }^{2}$ Corbin's chronology offers us a

\footnotetext{
1 On this see Ludovic Tournès, 'Reproduire l'œuvre: la nouvelle économie musicale', in Jean-Pierre Rioux and Jean-François Sirinelli, eds., La culture de masse en France, de la Belle Epoque à nos jours (Paris: Fayard, 2002), 220-58.

${ }^{2}$ For an initial approach to the problem and a bibliographical guide, see Tournès, 'Reproduire l'oeuvre'.
} 
preliminary approach. It is particularly clear as regards the I860s; Dominique Kalifa has also repeatedly pointed out the importance of this time of change. ${ }^{3}$ Corbin himself suggests that the change in the culture of sensation is not unconnected with the history of music as such: he notes that townspeople became progressively more intolerant of church bells in the I860s and comments that this was linked with the notion of the 'lie-in' (p. 280), which in turn was a consequence of the rise of latenight entertainment, particularly café-concerts. In this new urban culture, bells were no longer a prop to collective identity but an irritating noise.

Thus Corbin's 'landscape of sound' leads indirectly to a reassessment of the history of music since the late nineteenth century. In what follows I shall try to continue some of his lines of enquiry with the help of certain recent books on contemporary musical history.

\section{I9I4: brutalising the landscape of sound?}

The main aim of Glenn Watkins's erudite study Proof Through the Night is to probe the links between the First World War and the birth of musical modernism. The book arouses immediate interest and becomes more exciting if one shifts the viewpoint slightly and reads it as a contribution to the history of the contemporary landscape of sound - a history in which the Great War is undoubtedly a turning point.

The work's multinational approach (covering Britain, France, Germany, AustriaHungary, Italy and the United States) is both a strength and a weakness, since the treatment of these countries is very uneven. This is particularly true of Germany, which is at the core of the discussion but occupies only two chapters, devoted mainly to three Viennese composers, Schoenberg, Berg and Webern. This is all the more regrettable in that Germany was the fulcrum of the international musical world in I9I4: all other musical nations had to situate themselves willy-nilly by reference to Germany.

Watkins adopts the approach used by researchers into the culture of war (particularly Stéphane Audoin-Rouzeau) to show how music served as a vector of cultural mobilisation, as its emotive power was harnessed to strengthen popular hatred of the enemy. Convincing evidence comes from Watkins's analysis of certain works by Debussy, including Noël des enfants qui n'ont plus de maisons (Christmas carol for homeless children, I9I6) - a particularly emotive theme that was thoroughly exploited by the propagandists. Songs also served this function: Watkins cites the substantial corpus of songs about the lost provinces of Alsace-Lorraine that were regularly sung, even before the war, in Parisian café-concerts and helped to anchor the desire for revanche firmly in the French popular consciousness (p. II6); he also discusses the numerous songs - many of them now lost - which were sung in the trenches. Finally he traces the emergence of a 'war music' culture in the United States, a particularly interesting angle considering that the recording industry was much further advanced there than in Europe, going back to the beginning of the century. Bellicose songs

\footnotetext{
3 See esp. Dominique Kalifa, La culture de masse en France, I: 1860-1930 (Paris: La Découverte, 200I).
} 
began to be recorded after the sinking of the Lusitania in I9I5. Pacifists had their songs too: 'I Didn't Raise My Boy To Be a Soldier' sold more than 700,000 copies in I9I 5, showing that the swing in US public opinion, while it may have been rapid, was not unanimous. Once the United States entered the war, songs were unashamedly harnessed as aids to mobilisation and part of the war culture. 'Let's All Be American Now', by Irving Berlin, Edgar Leslie and George Meyer, and particularly 'Over There', by George Cohan, were hugely successful. The success of the latter went beyond the United States: Enrico Caruso, the world's most famous singer at the time, recorded a version in French. A total of 35,600 patriotic songs were deposited between I9I4 and I9I9 (not counting those which were never copyrighted), and 7,300 were published as scores and played not only in public, but also in US homes, many of which had acquired pianos after the turn of the century.

However, musical nationalism and war culture are not the most interesting aspects of Watkins's book, since here he is merely applying familiar approaches to the subject of music. His real originality, it seems to me, lies in his treatment of changes in the landscape of sound. He shows that the First World War was another turning point in the history of that landscape - first and foremost because of the unceasing, obsessive, and to contemporaries intolerable, omnipresence of noise. This was one of the worst aspects of life in the trenches, but is also one of the hardest to document. However, it seems clear that in I9I4 Corbin's 'society of silence' had given way to a society of continuous noise - as the Futurists were quick to note, and indeed to approve. This noise must have profoundly affected people's perception of sound, but it also affected artistic production. Here, paraphrasing George Mosse, we might describe the Great War as a 'brutalising' of the landscape of sound, ${ }^{4}$ but also, more profoundly, as engendering a new landscape of sound which was to widen in the I920s to include such novel components as the spread of the phonograph, the invention of electrical recording, the boosting of instrumental output by amplification, the development of radio and so on.

This makes Watkins's chapter Io perhaps the most interesting one in the book, since in it he uses a precise example of how music integrated new, war-related sources of sound: through a study of musical scores he shows how the war hastened the integration of aeroplanes and aero-engines into the musical landscape. This process began even before the war and seems to have owed a great deal to a rather unlikely mediator: Henry Deutsch de la Meurthe, an oil magnate and aviation enthusiast, donor of the eponymous trophy and founder in I9I I of the Paris Institut Aéronautique. He also had some musical talent and composed a large number of songs, including 'En dirigeable' ('In a dirigible', I908) and 'Vers les cieux. A la conquête de l'air' ('To the skies: the conquest of the air', I909). He was also a patron of the Ballets Russes - it is surely no coincidence that their scene painter, Natalia Goncharova, included some aeroplanes in a set in I9I 3 - and an acquaintance of Paul Painlevé, who was not only a mathematician but also a flying enthusiast, being the first Frenchman

\footnotetext{
4 George Mosse, Fallen Soldiers. Reshaping the Memory of the World Wars (New York and Oxford: Oxford University Press, I990).
} 
to make a flight with Wilbur Wright in I908. In the late I90os Deutsch de la Meurthe became an impassioned advocate of aviation to the French government. His songs use various devices to evoke the sound of aero-engines, and the same new musical trail was followed by the composer Maurice Ravel from I9I4. While Watkins supplies no proof that Ravel knew either Deutsch de la Meurthe or his musical works (which rather weakens his argument), he does show that Ravel was also keen on aviation and also knew Paul Painlevé. Ravel even tried to enlist as a pilot in I9I 5 , currying favour with Painlevé (then Minister for Education), to whom he dedicated his Trois beaux oiseaux $d u$ paradis which appeared the same year. But it is especially in Le Tombeau de Couperin, according to Watkins's analysis, that Ravel looks to aeroplanes for musical inspiration. This example of interaction between a composer, a politician and an industrialist shows that the changes in the landscape of sound involved the whole of society, far beyond the realms of music.

Ravel is all the more interesting here in that his enthusiasm for aviation was not ephemeral but continued after the war. He was also one of the first composers to go in for mechanical music and one of the few in his generation personally to supervise recordings of his works, showing interest in a medium which was ignored or even despised by other composers at the time. Where compositional methods were concerned Ravel was not in the avant-garde: in the rivalry between tonal music and the twelve-note scale (later serial music), which polarised the musical world until the I960s, Ravel was clearly in the neoclassical camp. But in the domain of recording techniques and the integration of new, contemporary noises into the landscape of sound, he was a pioneer: here we see the advantage of taking musical history out of the straitjacket of traditional musicology. The same approach could justifiably be used for such composers as the Americans Georges Antheil and Edgar Varèse, not to speak of genres such as jazz, which interested Stravinsky and other interwar composers precisely because it was, to an extent, mechanical. Here Watkins demonstrates the real usefulness of Corbin's suggested shift in viewpoint: it allows us to go beyond the history of music to the historicity of musical phenomena.

Another reason for regarding the Great War as a turning point is that it marks the advent of US music on the world stage: it was to contribute hugely to shaping the twentieth-century landscape of sound. Though the United States was already the world's leading industrial power by the beginning of the century, it was still tied to Europe's musical apron strings and particularly dependent on Germany, where so many composers, conductors and instrumentalists had their training. US originality had emerged rather in popular music, which since the late nineteenth century had been nourished by a dynamic entertainment industry. As far as serious music was concerned, the war was a major turning point in US emancipation from the European model, and one clear token of this was the expulsion of a number of German players and conductors from symphony orchestras in the wake of measures by the federal government against US citizens of German origin (Watkins cites the examples of Karl Muck, of the Boston Symphony Orchestra, and Ernst Kunwald, of the Cincinnatti Symphony orchestra), enhancing the 'Americanisation' of those orchestras. This is a phenomenon which would have repaid more detailed study. It is also worth noting 
that songs were a favourite resource used for the cultural mobilisation of American public opinion by the Committee on Public Information (CPI), 'the USA's first propaganda ministry' (p. 29I), set up by Woodrow Wilson to promote the concept of 'I00\% Americanism'. Finally, it is interesting that in I9I6 the United States officially adopted a national anthem, 'The Star-Spangled Banner', the most prominent token of the importance of the I9I4-I 8 war in the affirmation of US musical nationality. Thus the European war had a significant impact on the US musical landscape; it is also a key to understanding the global spread of US music in the twentieth century. Several factors were at work: the emergence of original music in a country whose sense of national identity was firmly fixed by the war, but also the modernist crisis in European music and, in my opinion, the abrupt shifts in the culture of sound during the war, leading to a new attitude to sound in the postwar period which was conducive to the reception of US music.

The spread of jazz in France, the subject of Jeffrey Jackson's Making Jazz French, is an example. Although Jackson is not the first to examine this subject (he devotes an appendix to a review of previous work), he offers an interesting synthesis of the problems of jazz history in France between the wars. He notes that France was only one of many countries to witness the international spread of jazz from I9I7 onwards, and that the process was almost simultaneous with its spread throughout the United States. Initially confined to the southern states, it spread all over the country between I9IO and I920, as musicians from New Orleans migrated to northern cities and sound recording developed. It would be wrong to think that one phenomenon followed the other. Jackson, concentrating on the French experience, also draws attention to two hitherto unnoticed aspects: the promptness of the appropriation (which began in the I920s) and the intensity of the debate over the subject of jazz and how the French used it to examine their own relationship with modernism. Here Jackson usefully fits the spread of jazz into a larger set of changes that hit France, particularly urban France, between the wars: more widespread electricity, development of the car, and so on. But jazz was more than a symbol of modernity: its spread in France also highlights a reconfiguration of the French landscape of sound, which can be perceived in the discourse it elicited. 'Tempest', 'tornado', 'infernal row', 'rage', 'domesticated catastrophe' (Jean Cocteau) and so on: jazz music was, first and foremost, a kind of auditory violence which some found exciting and others disquieting. Its spread was facilitated by the development of new media, such as radio and the gramophone, which were themselves the vectors of a new way of listening to music. This change to the landscape of sound was much influenced by the vast numbers of Americans present in France, whether as soldiers, tourists or musicians. The most important contributors were, of course, black musicians, members of orchestras that had come over in I9I7, who returned to establish themselves in Paris after demobilisation. Black people were very well represented in music-hall orchestras and fitted easily with the cosmopolitan Paris of the time (of its 2.9 million inhabitants in I92 I, 400,000 were foreigners) ${ }^{5}$ audiences loved them, French musicians resented them. Their success

5 Roger Nichols, The Harlequin Years. Music in Paris 1917-1929 (London: Thames \& Hudson, 2002), 9. 
was not just due to a passing fad: though they undoubtedly benefited from the vogue for the exoticism of 'l'art nègre', the acculturation of new sound forms of which they were the vectors was facilitated by the changes in auditory sensibilities brought about by the war. The fact that jazz took firm root in France and remains popular today ${ }^{6}$ supports this hypothesis, which has the merit of suggesting that the 'Americanisation' of the French landscape of sound should not be seen simply as a cultural import (or cultural invasion): some of its causes were internal. Jackson's work, like Watkins's, clearly shows that musical phenomena are not set in stone but are closely related to contemporary sensibilities: each helps to shape the other. This also emerges clearly from the book by Bernard Gendron.

\section{Legitimising popular art}

Between Montmatre and the Mudd Club is a more ambitious work than those discussed above. It ranges in time from the mid-nineteenth century to the present, and in space from France to the United States via Britain. Its central argument is that ongoing interchanges between the world of popular music and the world of the artistic avantgarde began to develop in the second half of the nineteenth century, first on the initiative and to the benefit of the avant-garde, which fed on popular music, and then, from the I940s onwards, vice versa, as popular music borrowed more and more freely from serious music and thereby gained a legitimacy and a stock of cultural capital which has since enabled it to cast off its alliance with serious music and win recognition on its own account.

Gendron situates the first turning point of this process in the France of the I 850 , contemporary with the birth of modernism (represented by Baudelaire and the 'art for art's sake' movement) and of mass culture (large-circulation newspapers, a burgeoning song industry, etc.). The interaction between these two domains became entrenched in the I 880 os with the rise of the Montmartre cabarets, which were important sites for the constitution and reception of avant-garde aesthetic practice (p. 3I), owing to the range of genres they exhibited (including popular songs, poetry and painting) as well as to their perennially experimental nature and taste for provocation. Cabaret, with its mingling of avant-garde and popular works, considerably extended the audience appeal of modernist aesthetics; the café-concert, followed by the music hall, were to do the same in the I890s, when the cabaret was in decline in France but became hugely popular in other European countries and served as the cradle of Dadaism (launched in Zurich's 'Voltaire' cabaret by Tristan Tzara), which was the ancestor of the twentieth-century avant-garde movements.

The second major turning point is I94Os America, when jazz graduated from pure entertainment to art - a change marked by the appearance of bebop, which borrowed heavily from classical music and so initiated a change in the dynamics of the popular music - avant garde relationship. Gendron notes that bebop brought popular music into the battle for cultural capital (p. I I), and New York supplanted Paris as the

\footnotetext{
${ }^{6}$ See Ludovic Tournès, New Orleans sur Seine. Histoire du jazz en France (Paris: Fayard, I999).
} 
favourite meeting place of pop art with the avant-garde. The transformation of jazz into an art gave rise to an aesthetic discourse and a lively dispute among fans, who, despite their disagreements, turned US negro music into an aesthetic category of its own. Gendron traces the start of this back to the dispute between supporters of New Orleans jazz and of swing, which began in the United States in I942; from 1946 this gave way to a dispute between New Orleanists and supporters of bebop, then just emerging on the New York musical scene. Gendron's argument is substantially convincing, but I must point out that a powerful and well-organised critical discourse had developed in France as far back as the early thirties, chiefly among on a group of enthusiasts who frequented the Hot Club de France (founded in 1932) and supported the magazine Jazz Hot (I935) and the works of their mentor, Hugues Panassié (Le jazz hot, I934, translated into English and published in the United States in I936; The Real Jazz, published in the United States in I942). This problem of chronology is a minor one, however, Gendron sees the artistic legitimising of jazz as an important change of hegemony whereby popular culture became a cultural - not merely economic threat to the privileged position of the classics (p. 7).

This process continued into the I960s with the legitimising of rock, which happened much more quickly than that of jazz, substantially between I964 and I969. These four years in the United States witnessed the new phenomenon of big trans-continental tours (such as that by the Beatles), the appearance of fanzines such as Crawdaddy (I966), the appearance of rock columns in existing newspapers (The Village Voice, I966), and all in all, a complete change in the discourse applied to both bands and their audiences. In sum, 'rock music' had become a recognised label whose history remains to be traced in detail.

After rock came the 'underground', which emerged in the I970s from the bars of New York. This movement, of which the leading lights were Patti Smith, the Ramones, Talking Heads, Blondie and others, was a reaction against the increasing blandness of rock. It was a conspicuous mix of genres (some groups performed in art galleries) and, again, relied on a community of fans and a network of fanzines. From I975 to I979, underground became punk and then new wave, shuttling to and fro across the Atlantic and establishing itself on the dividing line between mass culture and the avant-garde, in a chain of premises something between art galleries and rock clubs; the archetype was the Mudd Club, set up in 1978 in the New York district of TriBeCa, which was to pioneer the clubbing movement of the I980s.

I would dispute Gendron's analysis on one point, however: by focusing on discourse analysis he completely neglects other aspects which do not come into that category. He gives the impression that the legitimising of pop music is attributable solely to discourse and the filching of cultural capital from the sphere of classical art. This can be doubted. Was its legitimation not facilitated also by a change in the culture of sound which permitted the acceptance of types of music originally considered vulgar and or mere 'noise'? This is certainly true of jazz, as we have seen; it is also true of rock, whose overwhelming success coincided with the teenage years of the baby boomers, whose collective practices, including their musical sensibilities, deliberately broke with those of their elders. Electrical sound had a lot to do with it. 
Gendron notes that 1965 was a key year in the commercial take-off of rock, but does not seem to see this as the result of a definite musical event. I cannot agree: it can scarcely be a coincidence that it was in I965 that Bob Dylan first used an electric guitar at the Newport festival, and the Rolling Stones had an immense success with 'Satisfaction', its guitar riffs distorted by the use of a fuzz box. ${ }^{7}$ It was also in $1965-6$ that rock fans found a formal language of their own and created the first specialist journals, which were to make an important contribution to the legitimising of rock.

This discourse seems to have focused substantially on the idea of 'sound', a criterion which, since it made it possible to distinguish between the many variant styles included under the 'rock music' umbrella, served both as an academic tool enabling an alternative approach to music (breaking with traditional musicology which focused on melody and harmony at the expense of timbre) and as a commercial argument, since it provided a criterion for differentiating between the host of groups being promoted by the record companies. Finally, the producers of such discourse were themselves enthusiasts who used it to legitimise and formalise their own listening experience; there could scarcely be a better demonstration of the fact that the legitimising process is linked to the emergence of a new auditory sensibility which was conveyed to a wider public from the late I960s not only by articles in fanzines, but also by the marketing departments of record companies.

\section{Birth of a musical nation}

David Looseley's excellent Popular Music in Contemporary France represents further progress in analysing the legitimisation of popular art, in that it concentrates on France, where this legitimising movement was particularly marked. Looseley follows a recent shift in cultural studies away from the reception of cultural phenomena to the policies behind them. ${ }^{8}$ This enables him to examine a fundamental change in contemporary France - a nation once considered un- (or rather a-)musical, its cultural identity defined essentially through literature. Since I958, however, music has received unprecedented attention in France, culminating in official government recognition of pop music in the I980s, under the Socialist Minister of Culture, Jack Lang. The increasing prominence of music in the cultural landscape was inseparable from the penetration and 'naturalisation' (p. I) of British and US pop music, a fact which leads Looseley into an examination of the link between the legitimising of pop and questions of national identity, a link which seems to be particularly strong in France, where the state plays, perhaps, a larger part in cultural legitimisation - and in the construction of national identity - than anywhere else in the world. Hence Looseley argues that the legitimising of pop by Socialist cultural policies was one element in the redefinition of French national identity - and of an 'unconventional

\footnotetext{
7 François Bon, Rolling Stones. Une biographie (Paris: Fayard, 2002), 325. Note also that Bon stresses the impact on the fans of the amplified concert sound. This unprecedented loudness, created by electronic amplification, was one of the innovations of ig6os concerts.

${ }^{8}$ See esp. David Looseley, The Politics of Fun. Cultural Policy and Debate in Contemporary France (New York: Berg, I995).
} 
form of universalism' (p. 205) intended to counterbalance the worldwide domination of US music. A few years later the process culminated in the notion of the 'cultural exception'. The argument is persuasive, though I would not go as far as Looseley, who declares that written culture was 'steadily supplanted by the musical as a national paradigm' (p. 205).

Considered as a history of the landscape of sound, it is striking that this book tells us that French cultural policy after I98 I did no more than cast the spotlight on a movement that had existed within French society since the I96os. Using the results of surveys conducted from I973 onwards by the Ministry of Culture, Looseley shows that the social status of music in France changed totally somewhere between I960 and I990: this is revealed not only by changes in musical taste (especially the unprecedented advance of British and US music) but also by the explosive growth of amateur music making (helped by the availability of amplification), and the development of new technologies which, in the I980s, transformed the practices of listening to and making music by both amateurs and professionals: synthesisers, home studios, CDs, Walkmans, the Internet, and so on. The ground had already been prepared for this change in the musical landscape - by jazz, whose success in France between 1945 and 1960 paved the way for the acculturation of new sound patterns (including blues scales, which underlie almost all contemporary pop) and encouraged young people to go in for music making. Thus Jack Lang was tilling more fertile ground than it might first appear; and if the music festivals which symbolised his efforts were an instant success, it is because the French people were already attuned to them.

From this viewpoint, amateur music making has been an important cultural phenomenon over the last forty years, and is, I think, closely connected with a change in auditory sensibilities which I shall now attempt to analyse. Its first constituent is the omnipresence of recorded music. In the I930s records were luxury products; by the sixties, with the development of the LP and the Teppaz, they had become everyday consumer goods. Before the Second World War, listening to records was a solemn ceremony conducted by enthusiasts; for I960s teenagers it was almost a reflex action. Here is a symptom of the emergence of a new auditory sensibility which historians of music urgently need to take into account, following in the footsteps of Antoine Hennion ${ }^{9}$ (though Hennion has not delved into the historical background, a task which remains to be done). The other essential characteristic is the 'electrification' of listening. I have already mentioned 'Satisfaction' and Bob Dylan's electric guitar. It is worth adding that the spread of electrical instruments has not only democratised amateur music making (such instruments are less costly), but has also introduced new timbres into the ears of players, not to mention new levels of sound, new stances and new social networks that constitute a fertile field of research for the historian. The third characteristic is the musical melting-pot created by the mass invasion of the French musical landscape by British and US pop. Looseley shows how

\footnotetext{
9 See esp. Antoine Hennion, Les professionnels du disque, une sociologie des variétés (Paris: Métailié, I98I), and La passion musicale, une sociologie de la médiation (Paris: Métailié, I985).
} 
songs acted as catalysts for the naturalisation of rock in two ways. From the musical viewpoint, French songs from the I960s onwards borrowed sounds, instrumental arrangements and even actual songs from rock; symbolically, rock gained from the exchange something of the cultural aura which the songs owed to their affinity with literature, particularly poetry. The latter phenomenon is peculiarly French. France is not, of course, the only country where popular art became legitimised, but it is probably the only one in which literature played such an important part (both directly and indirectly) in that legitimation. Looseley shows that it would be simplistic to see French songs as a mere bulwark against Anglo-American musical imperialism; rather, they acted as a catalyst that enabled such pop to penetrate the French landscape of sound. An excellent example is 'world music', which was a big hit in France and which Looseley sees as a major indicator of the emergence of a new concept of national identity - and of an alternative to worldwide domination by US music. In the I950s French songs were assumed to be a purely French product; by the I980s, multiple mixings had turned them into a symbol of French-style multiculturalism and a vital ingredient of the notion of 'cultural exception' which emerged in that decade.

From the works reviewed here we may distil a number of useful guidelines for historians of sound. First, there are a number of turning points: the I 86os, the First World War and the I96os seem to be key periods in the history of the landscape of sound; they are the parameters of a vast process leading from the creation of a new landscape of sound in the late nineteenth century to the complete immersion of modern societies in continuous noise and their saturation with devices for musical reproduction. Second is a transnational perspective: historians working on these problems will gain enormously from crossing national boundaries and introducing a comparative dimension, particularly by looking at the international circulation of styles, artists, discourses and audiences. Within their own areas Watkins and Gendron have both responded, on the whole successfully, to this difficult challenge, so vital to an understanding of the twentieth-century musical scene. Third and last, are new objects for research, of which the most indispensable is probably the gramophone record, which is frequently mentioned but never thoroughly discussed in the works reviewed here. Its emergence was a turning point in the history of contemporary music, but it has been neglected by historians although it is an essential source for the history of the contemporary landscape of sound.

The above list is not, of course, exhaustive. It merely suggests certain lines of research which need to be further defined, supported or attacked by detailed research. There is plenty of archive material available. This is a subject which transcends national boundaries, and which hopefully will be the subject of future collaborative studies by European historians. 